\title{
2
}

\section{Narrative contexts for Bacon's New Atlantis}

\author{
P A UL SALZMAN
}

When Bacon wrote the New Atlantis, he clearly had More's Utopia in mind as a model, offering a small homage to it in a comment made by the 'good Jew': 'I have read in a book of one of your men, of a Feigned Commonwealth, where the married couple are permitted, before they contract, to see one another naked'. ${ }^{\text {I With }}$ great acuity, Susan Bruce has pointed out the significance of the family, and of desire, as a link between the two utopias. ${ }^{2}$ Bruce argues that in Bacon's utopia of Bensalem, More's male gaze of desire is replaced by a scientific elaboration of the value of male potency and procreation as a kind of state enterprise (in Bensalem a friend of each party views the naked potential partner). Bacon's vision does seem to me to be a deliberate counter to More's, in so far as it offers a world in which scientific knowledge structures society, as opposed to More's vision of a society structured by humanist ethics. I will argue later in this essay that Bruce's reading is particularly suggestive if we take into account the way that a later writer, Margaret Cavendish, unsettles the hierarchy of the patriarchal family in a utopia that, like Bacon's, is presented to the reader as an afterpiece following a scientific treatise. As a whole, this essay points to the way that the New Atlantis is richly allusive at the level of genre, gathering together, as it does, a range of reference to a wide variety of narrative possibilities.

If Bacon saw the New Atlantis as belonging to a fictional genre, it is not enough to say that the acknowledgement of More's Utopia means that this genre is 'the utopia'. ${ }^{3}$ While the date of 
composition of the New Atlantis is uncertain (probably I624), the 'utopian' works preceding and surrounding it are extremely disparate in nature. More's Utopia itself seems to have been interpreted in the early seventeenth century not so much as a particular kind of prose fiction as a particular kind of concept. This is most evident in Robert Burton's utopian musings in the preface ('Democritus Junior to the Reader') to The Anatomy of Melancholy, first published in I62I. Burton quotes extensively from Utopia, usually in reference to issues of moral reformation; for example, he writes 'our Trades generally ought to be reformed, wants supplied' and footnotes a quotation from Utopia Book One. ${ }^{4}$ In addressing these issues of reform, Burton was arguing his thesis that social abuses help to engender melancholy, and that society itself was a primary cause of the ailment that he analysed at such length in his treatise. In a famous quotation from the preface (spoken by Democritus), the manifold abuses of the world are outlined:

Judges give judgement according to their own advantage, doing manifest wrong to poore innocents, to please others. Notaries alter Sentences, and for money loose their Deedes. Some make false moneys, others counterfeit false weights. Some abuse their Parents, yea corrupt their own Sisters, others make long Libells and Pasquils, defaming men of good life, and extoll such as are lewd and vitious, some robbe one, some another; Magistrates make lawes against theeves, and are the veriest Theeves themselves. Some kill themselves, others dispaire not obtaining their desires. Some dance, sing, laugh, feast, and banket, whil'st others sigh, languish, mourne and lament, having neither Meat, Drinke, nor Cloathes. Some pranke up their bodies, and have their mindes full of execrable Vices. ${ }^{5}$

Burton's response to a diseased society is what might be called a utopian musing in which, again inspired by More as a model of argument rather than a creator of a genre, he imagines a place which is his fantasy of a more ideal society. This occurs in direct response to the thought that the evils of society cannot be redressed: 'there is no remedy' ${ }^{6}$ Burton writes:

I will yet to satisfie \& please my selfe, make an Utopia of mine owne, a new Atlantis, a poeticall commonwealth of mine owne, in which I will freely domineere, build Citties, make Lawes, Statutes, as I list my selfe. And why may I not? ${ }^{7}$ 
The reference to 'a new Atlantis' did not appear until the 1628 edition of Anatomy of Melancholy; in I62 I Burton began only by evoking Utopia as the poetical commonwealth. In the year following the publication of the New Atlantis, Burton, as was his habit, engaged in the process of accretion which characterised each successive edition of The Anatomy of Melancholy. The New Atlantis therefore forms a kind of pivot around which the notion of utopia shifts, in Burton's revision, from being a concept to something more approaching a genre. As Burton goes on, he evokes other precedents for his speculations: 'For the site, if you will needs urge me to it, I am not fully resolved, it may be in Terra Australis Incognita, there is roome enough (for of my knowledge neither that hungry Spaniard, nor Mercurius Brittanicus, have yet discovered halfe of it). ${ }^{8}$ In this sentence Burton points to the significant intersection of the utopian tradition and the travel narrative (both 'imaginary' and 'real'), which further complicates the generic context for the New Atlantis. Pedro Fernandez de Quiros' Terra Australis Incognita is his account of a Portuguese voyage which reached Vanuatu, but Quiros was convinced that he had reached the Great South Land and campaigned constantly for a colonising expedition. Terra Australis Incognita was translated from Latin into English (and French) in I6I7. Mercurius Britannicus is the purported author/protagonist of Bishop Joseph Hall's Mundus Alter et Idem ('A World Different and Yet the Same'), published in Latin in 1605 and in an English translation in I6og. I will return to Hall's work in detail below; it is important to note here that Mundus Alter et Idem is fiercely satirical, rather in the manner of Gulliver's Travels, and is quite different from the musings of Burton about an idealised world which will contrast with the diseased world of reality. Burton sees himself as creating his utopia, not discovering it: 'I will chuse a site. ${ }^{\prime 9}$

Burton's utopia is essentially a purged and reformed version of his own society: it will be orderly and regulated but not radically different, simply purified. Burton particularly favours hierarchy: 'Utopian parity is a kinde of government, to be wished for, rather than effected, Respub. Christianopolitana, Capanella's city of the Sun, and that new Atlantis, witty fictions, but meere Chimera's, and Platoes community in many things is impious, 
absurd and ridiculous, it takes away all splendor and magnificence.' то The three 'modern' examples coming before Plato were added to the text by Burton for the editions of 1628 and, in the case of Campanella, I638. Johann Andreae's Christianopolis (I6I9) is, like the New Atlantis, in part a vision of a scienceoriented society. ${ }^{\text {II }}$ Tommaso Campanella's City of the Sun was written in Italian in 1602 but published in Latin in I623. Ironically, both these utopias, like Bacon's, would be seen by most readers as clearly evoking hierarchical societies. Perhaps the key difference, for Burton, is that his utopia sustains a hereditary elite, though individuals are also to be elevated by election and by gift. Burton's government will, of course, be monarchical, but, as J. C. Davis has pointed out, the monarch is more of a figurehead, and real power is concentrated on a carefully structured social system which would, through various officials, ensure in particular an orderly economy. ${ }^{\mathrm{I2}}$ Burton writes:

If it were possible, I would have such Priests as should imitate Christ, charitable Lawyers should love their neighbours as themselves, temperate and modest Physitians, Politicians contemne the world, Philosophers should knowe themselves, Noblemen live honestly, Tradesmen leave lying and cosening, Magistrates corruption \&c. but this is unpossible, I must get such as I may. ${ }^{13}$

The line of irony that runs through Burton's fancy constantly draws our attention to the fact that this is a utopian projection with a clear sense of how individuals will always fail to live up to an ideal society.

Like Bacon, Burton envisages a society which values the pursuit of knowledge above all else: scholars are ranked above soldiers, and 'he that invents any thing for publike good in any Art or Science, writes a Treatise, or performes any noble exploit, at home or abroad, shall be accordingly enriched, honoured, and preferred. ${ }^{\prime 4}$ But Burton offers no real detail for this aspect of his utopia; indeed, he soon segues into his meditation on the fact that everyone is, in fact, mad, including himself (or at least himself in the persona of Democritus): 'I am as foolish, as mad as any one.' ${ }^{\prime 5}$ Burton always turns towards the narrator/meditator's self. Unlike Burton's self-reflexive text, Bacon's notion of narration owes more to the travel narrative, which offers another intersecting generic context for the New Atlantis. 
Bacon turns his back on the multiple, ironising frames within which More places his narrative. The reader of Utopia, by the edition of 15I8, moves from an address by Erasmus to John Froben, one by Budé to Thomas Lupset, maps of Utopia, its alphabet, Peter Giles's narration to Jerome Busleyden 'verifying' Raphael Hythlodaeus' account of Utopia, John Desmarais to Peter Giles, Busleyden to More, and More to Giles. We then reach the narrative 'of' Raphael Hythlodaeus. The actual narrative of the New Atlantis simply begins: 'We sailed from Peru, (where we had continued by the space of one whole year), for China and Japan, by the South Sea; taking with us victuals for twelve months; and had good winds from the east, though soft and weak, for five months' space and more' (457). Here we have the typical beginning of many a travel narrative. For example, 'The Discovery of Guiana', by Sir Walter Ralegh, in Richard Hakluyt's influential collection of English voyages, opens: 'On Thursday the 6. of February in the yere I595. we departed England, and the Sunday following had sight of the North cape of Spaine, the winde for the most part continuing prosperous: we passed in sight of the Burlings, \& the Rocke, and so onwards for the Canaries, and fel with Fuerte ventura the 17 of the same moneth, where we spent two or three dayes, and relieved our companies with some Fresh meat. ${ }^{\prime 6}$ The plain style of the travel narrative accorded well with Bacon's own ideal prose. The early modern travel narrative was intended not just to inform but also, frequently, to persuade. For example, de Quiros' Terra Australis Incognita is part of his scheme to persuade the King of Spain to colonise the great South land. What might be called the dry, factual description, particularly of places encountered, is a common component of this style; for example (from the same account):

The great river of Orenoque or Baraquan hath nine branches which fall out on the North side of his owne main mouth: on the South side it hath seven other fallings into the sea, so it disemboqueth by sixteene armes in all, between Ilands and broken ground, but the Ilands are very great, many of them as bigge as the Isle of Wight, and bigger, and many lesse. From the first branch on the North to the last of the South, it is at least Ioo leagues, so as the rivers mouth is 300 miles wide at his entrance into the sea, which I take to be farre bigger then that of Amazones. ${ }^{17}$ 
Where de Quiros advocated a colonial venture, Bacon uses New Atlantis to advocate a scientific paradigm for the pursuit of knowledge. John Gillies has pointed to Bacon's interest in the idea of travel as a parallel to his notion of scientific advancement. ${ }^{18}$ This is part of Bacon's attack on the reliance upon the ancients for scientific knowledge. In Novum Organum (1620), Bacon states:

Nor must it go for nothing that by the distant voyages and travels which have become frequent in our times, many things in nature have been laid open and discovered which may let in new light upon philosophy. And surely it would be disgraceful if, while the regions of the material globe - that is, of the earth, of the sea, and of the stars - have been in our times laid widely open and revealed, the intellectual globe should remain shut up within the narrow limits of old discoveries. ${ }^{19}$

Gillies notes how:

Bacon fully recognised the importance of the voyager myth to his age and made a concerted effort to transform it into a metaphoric vehicle of the experimental method. The frontispiece to the Instauratio Magna (I620) shows a ship sailing out through the Pillars of Hercules. $^{20}$

In the New Atlantis, the voyage allows Bacon to incorporate his scientific ideal within the society of Bensalem.

As a travel narrative, the New Atlantis is full of allusions to the significance of colonial endeavours by England and its competing European powers in the quest for possession, as well as knowledge. The travellers are met by a 'delegation' from New Atlantis and are spoken to in Spanish. They are offered an elaborate explanation when they ask why 'this happy island where we now stood was known to few, and yet knew most of the nations of the world; which we found to be true, considering they had the languages of Europe, and knew much of our state and business' (466). Under the provisions by the great and wise Solamona, the island has deliberately set out to exclude those who might attempt to assimilate it into colonial enterprise, yet a carefully controlled series of explorations (every twelve years) ensure that the flow of knowledge into the island will be constant: 'in either of these ships there should be a mission of three 
of the Fellows or Brethren of Salomon's House; whose errand was only to give us knowledge of the affairs and state of those countries to which they were designed, and especially of the sciences, arts, manufactures, and inventions of all the world' (47I). Bacon's vision of the New Atlantis entails an incorporation of colonial endeavours as part of the general expansion of knowledge.

However, the techniques of the travel narrative also form part of the satirical tradition of imaginary voyages, utopias and dystopias; the ready evocation of verisimilitude lends itself to parody and manipulation. (One could argue that this ambiguity is present from the very start, as both imaginary and 'real' travel narratives overlap in so many ways, from classical times through the conduit of someone like Sir John Mandeville to the early modern period.) Joseph Hall's Mundus Alter et Idem is a satirical account (complete with detailed maps) of the journey of Mercurius Brittanicus to a world of vice and excess. It begins with the lure of armchair travel: 'Contrary to expectation, dear Reader, driven neither by storms nor by the never-ending tossings of waves, without winds, without sails, you have been driven to a new world. ${ }^{21}$ The readers of travel narratives are teased into a satire directed both at travel itself and the imaginings of travellers, and also at the vices of the contemporary world. As Richard McCabe notes, 'In Hall's eyes the wanderlust of his contemporaries was indicative of their vanity, idleness and greed. Their desire for the marvellous - whether marvellous wealth or marvellous experiences - was a symptom of their moral decline. ${ }^{22}$ In the preface our attention is drawn to the journey to Ophir by Solomon and Hiram (see Kings 9.26-8). This points to Terra Australis Incognita, or at least to the imaginings associated with it. Then the satire commences, the first place reached being Crapulia. As Hall's satiric account of Mercurius Brittanicus's journey proceeds, the travel narrative becomes the vehicle for a fairly broad sweep at a variety of vices (such as gluttony).

Milton famously condemned Hall for offering, in Mundus, self-indulgent satire which revelled in the vices it described, as opposed to the sober virtues of true utopias:

That grave and noble invention which the greatest and sublimest wits in sundry ages, Plato in Critias, and our two famous countrymen, the one in his Utopia, the other in his new Atlantis chose, I 
may not say as a field, but as a mighty Continent wherein to display the largenesse of their spirits by teaching this our world better and exacter things, then were yet known, or us'd, this petty prevaricator of America, the zanie of Colombus, (for so he must be till his worlds end) having rambl'd over the huge topography of his own vain thoughts, no marvell, if he brought us home nothing but a meer tankard drollery, a venerous parjetory for a stewes. Certainly he that could indure with a sober pen to sit and devise laws for drunkards to carouse by, I doubt me whether the very sobernesse of such a one, like an unlikour'd Silenus, were not stark drunk. ${ }^{23}$

Milton's attack may be part of a general polemic against Hall, rather than Milton's final thoughts on the utopian form, but it points to some of the tensions (as well as interconnections) between utopia and dystopia. Hall's narrative is satirical throughout, but the voyage that Mercurius Brittanicus describes is a geographically detailed voyage (however much it is at the same time a satirical one), complete with detailed maps of the lands he visits. Indeed, one interesting comparison with the New Atlantis is the somewhat perfunctory way in which Bacon sets up his account of his imaginary land: there are no maps provided (although it is true that the New Atlantis remained incomplete, so we cannot be absolutely certain that Bacon did not intend to provide one). Mundus Alter et Idem satirises the idealising imagination which calls a utopia into existence in the first place, and this is done via a satire on the travel narrative's tendency to revel in both the marvellous and the potential wealth of the new world being described. Hall also satirises the claims for geographical knowledge exemplified in a work like Peter Heylyn's Microcosmus (I62 I), a typical example of the comprehensive geographical description available in the seventeenth century. Heylyn claims that 'Historie without Geographie like a dead carkasse hath neither life nor motion at all.' ${ }^{24}$ For Hall, geographical knowledge, like the travel narrative, is a particular example of worldly pride and accordingly it is a fitting target for his satire. In contrast, Bacon offers Bensalem as an ideal society and the voyage to it as a fortuitous discovery of an ideal.

The intersection between travel narrative, dystopia and imaginary voyage in relation to the New Atlantis can be illustrated by turning to the kind of source criticism now completely 
unfashionable, but once the mark of true scholarship. It can serve to indicate the sorts of links that suggest themselves to 'empirical' scholars who look back at a work like the New Atlantis. In his study of the influence of voyagers on Elizabethan literature, Robert Cawley points to two 'sources' for the New Atlantis: William Adams' voyage to Japan and de Quiros. ${ }^{25}$ In the case of Adams, Cawley is able to point to some interesting parallels with the opening of the New Atlantis. Adams' voyage begins in I598, and during the first part many sailors become ill, and are put off ship at 'the coast of Gynny' ${ }^{26}$ The voyage, like that of the New Atlantis, moves from Peru towards Japan for five months via the Straits of Magellan. Adams arrives to a welcome not dissimilar to that meted out by Bensalem:

the King of Bungo, the place where we arrived, did us great friendship. For he gave us an house on shore for our sick men, having all refreshing that was needfull. We had when we came to anchor in Bungo foure and twentie men, sicke and whole, of which number the next day three dyed, the rest for the most part recovered, saving three which lay long time sicke, and in the end also died. ${ }^{27}$

Adams is sent for by the Emperor, and offers an account of English merchant enterprise. The Emperor orders the mariners to remain in Japan, making provision for them. Japan, like Bensalem, is carefully shielded from outside influences.

For a source-hunter like Cawley, the sole issue here is whether or not Bacon read Adams' account. However, for what we might call generic considerations, what is interesting is the desire to relate the 'realist' detail at the beginning of the New Atlantis to an actual voyage narrative like Adams' ${ }^{28}$ (It is worth noting that Adams' account is in the form of two letters sent from Japan: one general letter 'To my unknowne Friends and Countrey-men', the second to his wife. ${ }^{29}$ This produces a very strong sense of transparency and directness in the narrative.) Cawley also cites Terra Australis Incognita, again looking for details which mesh with Bacon's account of the initial voyage which ends up at Bensalem, but also pointing to de Quiros' idealistic view of the great Southern continent. Cawley emphasises the Spanish connection here (given that Spanish is the European language spoken by the Bensalem representatives). Again, this raises the issue of the colonial spirit behind the New Atlantis, given that de Quiros is principally 
concerned to hawk Terra Australis to the King of Spain as a suitable place to settle: 'If vpon a bare suspition Christoferus Columbus did pursue his designe with so much obstinacie, you are not to account it strange in me if the things which I haue beheld with mine eyes, and touched with mine hands, doe put some kind of constraint vpon me to be importunate'..$^{30}$

With the travel narratives in mind, we perhaps need to ask when the utopian part of the New Atlantis actually begins. 'Our' voyage from Peru is curiously anonymous compared to an account like Adams', which carefully establishes the narrator's identity and bona fides to begin with:

I am a Kentish-man, borne in a Towne called Gillingham, two English miles from Rochester, one mile from Chattam, where the Kings ships lye: and that from the age of twelve yeares, I was brought up in Lime-house neere London, being Prentise twelve yeares to one Master Nicholas Diggines, and have served in the place of Master and Pilot in her majesties ships, and about eleven or twelve yeares served the Worshipfull Company of the Barbarie Marchants, untill the Indian Trafficke from Holland began, in which Indian Trafficke I was desirous to make a little experience of the small knowledge which God had given me. So in the yeare of our Lord God I598. I was hired for chiefe Pilot of a Fleete of five sayle. ${ }^{3 \mathrm{I}}$

Bacon's narrative may use similar voyage details, but his narrator is without any clear identity; indeed, he is something of a cipher. Bacon's interest in verisimilitude is, therefore, more a matter of narrative detail than of anything we might call characterisation. In fact, he shows no real interest in the Bensalemites as individual characters (or even as types); they are more like mouthpieces for the social and scientific aspect of the narrative. The speeches of the narrator are exemplary in the same way that the Bensalemite speeches tend to be: 'I thought good to call our company together; and when they were assembled said unto them; "My dear friends, let us know ourselves and how it standeth with us."' (46r). When it begins, the account of Bensalem is not greatly dissimilar to Adams' description of Japan: "'We of this island of Bensalem (for so they call it in their language), have this; that by means of our solitary situation, and of the laws of secrecy which we have for our travellers, and our rare admission of strangers, we know well most part of the habitable world, and are ourselves 
unknown"' (463). Of course the 'history' of Bensalem is narrated back to 'three thousand years ago'. Plato's account of Atlantis is cited: while it is 'all poetical and fabulous: yet so much is true, that the said country of Atlantis, as well that of Peru, then called Coya, as that of Mexico, then named Tyrambel, were mighty and proud kingdoms in arms, shipping and riches' $(467-8)$. The destruction of Atlantis impacts upon Bensalem's trade and this brings the history forward to the edicts of the wise king who, 'about nineteen hundred years ago' (469), decided that Bensalem should stay out of the world's eyes.

Throughout this stage of the narrative we are in the province of 'true' history and geography. When does this pass into utopia? I would argue that this transition does not occur until about half way through the text of the New Atlantis (as we have it), when Salomon's House is first mentioned (47I). At this point the narrative still resembles the travel account, but when Bacon begins to describe the society which stems from the creation of Salomon's House, the utopian vision becomes incorporated with the travel narrative. The two remain intertwined when we are informed of the careful regulation of traffic with the outside world (this is the section which Cawley sees as reminiscent of Adams' account of Japan):

When the king had forbidden to all his people navigation into any part that was not under his crown, he made nevertheless this ordinance; That every twelve years there should be set forth out of this kingdom two ships, appointed to several voyages; That in either of these ships there should be a mission of three of the Fellows or Brethren of Salomon's House; whose errand was only to give us knowledge of the affairs and state of those countries to which they were designed, and especially of the sciences, arts, manufactures, and inventions of all the world; and withal to bring unto us books, instruments, and patterns in every kind. (47I)

Here Bacon links the history of Bensalem's attitude towards travel with its idealised society - a society that is carefully protected from the outside world but not insular.

As Bacon moves into an analysis of the society created in Bensalem, which has at its heart the institution of Salomon's House, the narrative glances at more peripheral genres which touch upon political commentary. The most interesting example of these is the kind of political and didactic commentary that 
seeped into fiction early in the seventeenth century. None of this material can be described as utopian, but it may be allied with the utopian mode in so far as it sees fiction as a vehicle for serious social or political commentary. In Censorship and Interpretation, Annabel Patterson has traced the complex methods by which literature in the early modern period searched out ways of making political comment beneath a general blanket of censorship..$^{32}$ In particular, she notes the way that the romance form became politicised in the early seventeenth century. This is most evident in the work of John Barclay. Barclay grew up in France, the son of a Scottish father and a French mother. Around I603 he became a quite important figure in the court of James I, having already made a name for himself in Europe with the publication of Euphormio's Satyricon, in Latin, in I605. This work is generally classified as belonging to the rather ill-defined genre of Menippean satire: a mix of allegory, picaresque narrative and satirical commentary. ${ }^{33}$ Barclay dedicated Part One to James and Part Two (which was published in I6ro) to Robert Cecil, Earl of Salisbury. In the dedication to James, Barclay stresses the satirical nature of his book: 'my bitter attack in this book against the crimes of the world'. ${ }^{34}$ Euphormio's Satyricon shares the satirical impulse of Hall's Mundus Alter et Idem, which also has the characteristics of Menippean satire. ${ }^{35}$ Barclay begins with the narrator Euphormio's paean to his utopian country Lusinia:

Here no one worships fancy furniture, jewels, power, wealth, or any of those things on which the sterile lust of men sets a high price. Here, if anyone is at all enthusiastic about the pursuit of virtue, he is immediately raised to a magistracy in an honest election; and he inspires all with envy of his way of life, none with envy of his position. ${ }^{36}$

Euphormio then immediately launches into an attack on the 'depraved inhabitants of earth' who are venal and corrupt. ${ }^{37}$ The narrative in fact details Euphormio's picaresque journey through the 'real' world, enumerating vices en route. The narrative offers thinly disguised accounts of the Spanish Netherlands and Paris. In Part Two, he visits Italy and then the court of Henry IV, but finally arrives at the court of James (named King Tessaranactus in the narrative) in London and concludes with a glowing account of James's country and character. Euphormio's travels through 
Europe, while very much in the picaresque mode, evoke the travel narratives discussed above and also the accounts by individual travellers through Europe, the most famous in England being Coryate's Crudities (I6I I), Thomas Coryate's account of a journey (mostly on foot) from England to Venice and back.

Barclay's editor, David Fleming, points out the significance of Barclay's use of allegorical references to current events and people in Satyricon: a technique that was taken up by other writers during the seventeenth century.$^{38}$ These direct references are a change from the way some forms of fiction, such as Philip Sidney's Arcadia, may have offered glancing portraits of contemporary situations or general political commentary. They point towards a growing sense that prose fiction is an appropriate medium for social and political commentary and thus provide a further context for the New Atlantis, gathering up elements from an increasingly varied mixture of genres and modes. ${ }^{39}$ In particular, Bacon uses the combination of voyage/utopia to encapsulate an account of England's social failings as well as a picture of the ideal society to which it might aspire. In Satyricon, Barclay offers a portrait of England (Scolimorrhodia $=$ thistle $/$ rose, a compliment to James for uniting Scotland and England) which is both admiring and critical: 'I was in wonder at this happy region ... But the people (as happens often) were fattened by excessive fortune and had replaced the resourceful initiative that results from poverty by a proud laziness.' ${ }^{\circ}$ But the aristocratic inhabitants (according to Euphormio) are another matter: 'When I considered the conversation of the great men and the good-breeding of their daughters, they somehow seemed to me more blessed than heaven itself.' ${ }^{4}$ At this point the narrative ends rather abruptly with a poem in praise of James, and we don't receive many details about Scolimorrhodia, but we do glimpse a (politically astute) comparison between an idealised England and a satirised Europe.

Barclay's second major prose work was a political romance called Argenis, first published in Latin in I62 I. James asked Ben Jonson to translate it into English, but after his translation was apparently lost in the infamous fire of 1623, Kingesmill Long published an English translation in $\mathrm{r} 625$, followed by another by Robert Le Grys in 1628.4² (Argenis was also translated into a number of European languages and was widely reprinted in Latin 
during the seventeenth century.) Argenis is quite different from Euphormio's Satyricon: it works with the romance tradition, but uses an allegorical method to depict both contemporary and historical individuals and events. Argenis is actually set in France at the time of Henry III and Henry IV, but it also includes more contemporaneous events, such as the Overbury scandal. At the same time, Barclay offers a purely fictional narrative through which he examines more abstract political issues.

Annabel Patterson has pointed to the significance of Barclay's use of fiction for political purposes. ${ }^{43}$ She notes in particular the philosophical discussion led by Nicopompus (Barclay's selfportrait), which revolves around the way that fiction might (through disguised representation) take up political and historical events. Nicopompus offers a description of the kind of literature of which Argenis itself is an exemplar:

I will compile some stately Fable, in manner of a History: in it will I fold up strange events ... The Readers will be delighted with the vanities there shewne incident to mortall men: and I shall have them more willing to reade mee, when they shall not find me severe, or giving precepts. I will feed their minds with divers contemplations, and as it were, with a Map of places ... because I seem to tell them Tales, I shall have them all: they will love my Booke above any Stage-play, or spectacle on the Theater ... While they reade, while they are affected with anger or favour, as it were against strangers, they shall meete with themselves; and finde in the glass held before them, the shew and merit of their owne fame ... he may be as much deceived, that would draw all in my writing, as he that would nothing, to the truth of any late or present passage of State. ${ }^{44}$

Argenis exemplifies these precepts of Nicopompus, containing, as it does, an account of European events and an analysis of significant individuals fictionalised in such a way that general moral doctrines may be discerned by the reader. Barclay's narrative is not simply a roman à clef, but a fictional re-creation of historical events for a specific political purpose.

Patterson stresses that Argenis represents a particular moment in the use of literature to circumvent censorship and open up a political dialogue which will simultaneously reach the reader and protect the writer..$^{45} \mathrm{I}$ am not arguing that these works of Barclay are a direct influence on the New Atlantis, but rather that they 
establish a particular context for the intersection between fiction and social comment. Bacon in disgrace and enforced retirement did not simply perfect his scientific writings, he also turned to a mode of writing that might at first sight seem quite different from all his other works, however varied they might be. In their recent biography of Bacon, Lisa Jardine and Alan Stewart offer a particularly interesting description of how Bacon:

tacitly erased all signs that his 'thought' and his 'life' (in the political arena) had hitherto been intimately linked. Instead he constructed a 'before' and an 'after': before, Francis Bacon was an active politician, caught up in the hurly-burly of court and parliamentary affairs, his outlook inevitably coloured (not to say tarnished) by the times; after, he was a patrician thinker, selflessly pursuing his scientific endeavours for posterity..$^{4}$

Just as Jardine and Stewart point to this divide as an artful construct, so I would want to argue that New Atlantis is a perfect fictional negotiation of the shift between active political comment and 'neutral' speculation. As a narrative, the New Atlantis operates in the space between direct political intervention and private political musing: the space that various quite disparate forms of fiction helped to create in the early seventeenth century. From this perspective, the New Atlantis can be linked to Bacon's non-fictional writing in what we might at a stretch call other narrative forms, such as the history, or the dialogue. Having played the complicated Jacobean political game for the highest stakes and lost, Bacon uses the New Atlantis to offer a vision of a society dedicated to scientific advancement, but he also uses it indirectly to convey a political vision of an ordered society (in which, in various ways, a Francis Bacon would receive his just desserts).

With this in mind, I want to conclude by looking at one last generic issue for the New Atlantis: the specific way in which the narrative is actually situated. The modern reader who encounters the New Atlantis as part of an anthology (such as the Brian Vickers' collection, or the old World's Classics edition of The Advancement of Learning and New Atlantis) has a quite different experience of the text from the seventeenth-century reader. ${ }^{47}$ In I627 Bacon's chaplain William Rawley oversaw the publication of Sylva Sylvarum: or, A Natural History in Ten Centuries. This is what might be called a miscellany of scientific curiosities, experiments 
and information. Much of the material was gathered by Bacon from ancient sources, such as Aristotle, but Bacon also made considerable use of Sandys' Travels (I6I5) for material about Greece, the Middle East and Italy. Sylva Sylvarum is broken up into one thousand brief, numbered paragraphs (arranged in ten 'centuries'). Here is an entirely random example:

Experiment solitary touching cements and quarries.

850. There have been found certain cements under earth that are very soft; and yet, taken forth into the sun, harden as hard as marble: there are also ordinary quarries in Somersetshire, which in the quarry cut soft to any bigness, and in the building prove firm and hard..$^{8}$

At the conclusion of Sylva Sylvarum, a new title page announces New Atlantis. A Work unfinished. There is then a note from Rawley headed 'To the Reader' in which both the genre and the placement of the New Atlantis are carefully explained:

This fable my Lord devised, to the end that he might exhibit therein a model or description of a college instituted for the interpreting of nature and the producing of great and marvellous works for the benefit of men, under the name of Salomon's House, or the College of the Six Days' Works. And even so far his Lordship hath proceeded as to finish that part. Certainly the model is more vast and high than can possibly be imitated in all things; notwithstanding most things therein are within men's power to effect. His Lordship thought also in this present fable to have composed a frame of Laws, or of the best state or mould of a commonwealth; but foreseeing it would be a long work, his desire of collecting the Natural History diverted him, which he preferred many degrees before it.

This work of the New Atlantis (as much as concerneth the English edition) his Lordship designed for this place; in regard it hath so near affinity (in one part of it) with the preceding Natural History. ${ }^{49}$

So this work is a fable, but it nevertheless belongs with Sylva Sylvarum because, through the fable, Bacon offers an exemplary scientific society. The two works accordingly form an intersecting genre of natural history/fable, treatise/fiction, which readers were encouraged to see as inseparable. The New Atlantis was included in all the seventeenth-century editions of Sylva. It was included in Bushell's Abridgement of I659. It was also published 
separately in Latin in the I638 Operum Moralium and, significantly, paired with Hall's Mundus in an edition of $1643 . .^{\circ}$ The New Atlantis and Sylva Sylvarum form an implied commentary on each other. Given Rawley's stress on the word fable as a description of the New Atlantis, it is worth noting the way he concludes his Preface to Sylva Sylvarum: 'I will conclude with an usual speech of his lordship's; That this work of his Natural History is the world as God made it, and not as men have made it; for that it hath nothing of imagination' ${ }^{5}{ }^{51}$ So the New Atlantis might be seen as the vision of the natural history with the addition of imagination. It is also, in many ways, a kind of reaching forward in time for Bacon, who, if he is unable to perfect his scientific work, is able at least to imagine a world in which a whole society would be devoted to such perfection. Bensalem is also, of course, shot through with other forms of Baconian wishfulfilment, such as the obsessive, luxurious social ceremony of the Feast of the Family (472-5).

This intersection of scientific treatise and utopia might be viewed as a late version of the general Renaissance interest in mixed modes.$^{52}$ The result is not so much a specific form of fiction as a specifically productive yoking of fiction with something else. Recently, scholars working on Margaret Cavendish have noticed the parallel between Cavendish's utopian Blazing World and the New Atlantis. ${ }^{53}$ In 1666 Cavendish published Observations Upon Experimental Philosophy, an attack on Robert Hooke's Micrographia of 1665 . Cavendish attached to Observations, with a separate title page, The Description of a New World Called The Blazing World. She states in a preface to the reader, 'If you wonder that I join a work of fancy to my serious philosophical contemplations, think not that it is out of a disparagement to philosophy.' 54 Like the New Atlantis, Blazing World creates a society in which the author's scientific ideas are taken up by a protoRoyal Society (in Cavendish's case composed of a number of beast-like creatures, rather than human beings). Cavendish also answers Bacon's celebration of patriarchal authority with a vision of a female society, ruled by an Empress who is joined by Cavendish's own spirit in the Blazing World. In this sense, Cavendish argues against the male potency and dominance of a patriarchal family structure which Susan Bruce sees as essential 
to Bacon's purpose in the New Atlantis. ${ }^{55}$ Cavendish offers an antidote to Bacon's masculine society by way of a society in which the Emperor is a cipher who allows the Empress complete domination over his world. Just as Bacon envisages a society oriented both towards his dreams of science and full of ceremony and degree, Cavendish imagines a world in which both her dramatic and her scientific writing is appreciated. Of course it is Bacon who provides a context for Cavendish, rather than the other way round, but Cavendish's Observations/Blazing World diptych draws our attention to the way that Bacon's Sylva/the New Atlantis is a particularly hybrid example of a particularly hybrid genre.

\section{Notes}

I Brian Vickers (ed.), Francis Bacon: A Critical Edition of the Major Works (Oxford, Oxford University Press, I996), p. 478. All further references to New Atlantis are from this edition. More's Utopia was first published in Latin in I516, followed by many other editions and an English translation by Raphe Robinson in I55I.

2 Susan Bruce, 'Virgins of the world and feasts of the family: sex and the social order in two renaissance utopias', in Neil Rhodes (ed.), English Renaissance Prose: History, Language and Politics (Tempe, MRTS, I997), pp. I39-46.

3 J. C. Davis argues that, during this period, 'utopian thought itself is not a tradition', Utopia and the Ideal Society (Cambridge, Cambridge University Press, I98I), p. 3 .

4 Robert Burton, The Anatomy of Melancholy, ed. Thomas Faulkner et al. (Oxford, Clarendon Press, I989), vol. I, p. 80; the copytext is the greatly augmented I632 edition; in this instance the quotation is in the I62I edition. For the actual Utopia quotation see Complete Works of St Thomas More, ed. Edward Surtz and J. H. Hexter (New Haven, Yale University Press, I965), vol. IV, p. 70.

5 Burton, Anatomy, pp. 36-7.

6 Ibid., p. 85.

7 Ibid.

8 Ibid., p. 86.

9 Ibid.

Io Ibid., p. 89.

I I For a good account see Frank and Fritzie Manuel, Utopian Thought in the Western World (Cambridge, Mass., Bellknap Press, I979), Chapter I I.

I2 See Davis, Utopia, pp. 97-8.

I3 Anatomy, p. 9I. 
I4 Ibid., p. 92.

I5 Ibid., p. Iog.

I6 Richard Hakluyt, Principal Navigations, Voyages Traffiques and Discoveries (Glasgow, Glasgow University Press, 1904), vol. X, pp. 348-9.

I 7 Ibid., p. 382 .

I8 John Gillies, Shakespeare and the Geography of Difference (Cambridge, Cambridge University Press, I994), p. 223.

I9 Francis Bacon, The New Organon, ed. Fulton Anderson (New York, Liberal Arts Press, I960), p. 8I.

20 Gillies, Shakespeare, p. 223, n. 98.

2 I Another World and Yet the Same: Bishop Joseph Hall's Mundus Alter et Idem, trans. John Miller Wands (New Haven, Yale University Press, I98I), p. 3 .

22 Richard A. McCabe, Joseph Hall: A Study in Satire and Meditation (Oxford, Clarendon Press, i982), p. 76.

23 Complete Prose Works of John Milton, ed. Don M. Wolfe (New Haven, Yale University Press, I953), vol. I, p. 88I. I should note here that this is from 'An Apology Against a Pamphlet' ( 1642 ), a direct attack on Hall. The editor points out that Milton offers a quite different view of Utopias in Areopagitica, where he writes 'To sequester out of the world into Atlantick and Eutopian polities, which never can be drawn into use, will not mend our condition; but to ordain wisely as in this world of evill, in the midd'st whereof God hath placed us unavoidably,' Complete Prose Works, ed. Ernest Sirluck (New Haven, Yale University Press, I959), vol. II, p. 526.

24 Peter Heylyn, Microcosmus (Oxford, I62 I), p. I I.

25 Robert Ralston Cawley, Unpathed Waters: Studies in the Influence of the Voyagers on Elizabethan Literature (1940, rpt. New York, Octagon, 1967), pp. $44^{-} 7$.

26 'William Adams his Voyage by the Magellan Straights to Japon', in Samuel Purchas, Hakluytus Posthumous or Purchas his Pilgrims (Glasgow, Glasgow University Press, I905), vol. II, p. 327; Adams' account was published by Purchas in 1625 .

27 Ibid., p. 332.

28 Cawley concludes that Bacon's knowledge of Adams can only be conjectural, because Adams' account was published after the likely composition date of New Atlantis. See Cawley, Unpathed Waters, pp. $44^{-5}$.

29 Purchas, Hakluytus, p. 339.

30 Ferdinand de Quiros, Terra Australis Incognita (I6I7), p. 27.

3I Purchas, Hakluytus, p. 327.

32 Annabel Patterson, Censorship and Interpretation: The Conditions of Writing and Reading in Early Modern England (Madison, University of Wisconsin Press, 1984). 
33 John Barclay, Euphormionis Lusinini Satyricon, ed. and trans. David A. Fleming (Nieuwkoopp, de Graaf, I973), p. xvi.

34 Ibid., p. 3.

35 See McCabe, Joseph Hall, p. 76 and my discussion above.

36 Euphormionis, p. 5.

37 Ibid., p. 5 .

38 Ibid., p. xx.

39 I have argued this case at greater length in English Prose Fiction 1558I700: A Critical History (Oxford, Clarendon Press, I985), Chapter I I.

40 Euphormionis, p. 349.

4 I Ibid., p. 35I.

42 For full details see Salzman, English Prose Fiction, pp. I49-55.

43 Patterson, Censorship, p. I8o.

44 John Barclay, Barclay His Argenis, trans. Kingesmill Long (I625), p. Iog.

45 See Patterson, Censorship, pp. I8I-3.

46 Lisa Jardine and Alan Stewart, Hostage to Fortune: The Troubled Life of Francis Bacon (London, Victor Gollancz, I998), p. 475.

47 Vickers (ed.), Francis Bacon; Advancement of Learning and New Atlantis, ed. Thomas Case (London, Oxford University Press, I906).

48 The Works of Francis Bacon, ed. James Spedding, Robert Ellis and Douglas Denon Heath, I4 vols (London, I857), vol. II, p. 620.

49 Ibid., vol. III, p. I27.

50 See R. W. Gibson, Francis Bacon: A Bibliography (Oxford, Scrivener Press, I950).

5I Bacon, Works, vol. II, p. 337.

52 See Rosalie Colie, The Resources of Kind (Berkeley, University of California Press, 1973).

53 See especially Bronwen Price, 'Journeys beyond frontiers: knowledge, subjectivity and outer space in Margaret Cavendish's The Blazing World', Literature and History, 7 (1998), 2I-50: Price specifically discusses Cavendish's argument with Bacon's view of science, pp. 25-3I; see also Marina Leslie, Renaissance Utopias and the Problem of History (Ithaca, Cornell University Press, I998), p. I23; as yet unpublished work on this issue has been done by Sarah Hutton, Rebecca Totaro and Debra TaylorPearce; I am grateful to them for drawing their work to my attention.

54 An Anthology of Seventeenth-Century Fiction, ed. Paul Salzman (Oxford, World's Classics, I99I), p. 25I.

55 For Bruce's reading see above, note 2. 